\title{
Grape extract and $\alpha$-Tocopherol effect in cardiovascular disease model of Apo E -/- Mice ${ }^{1}$
}

\author{
Efeito do extrato de uva e $\alpha$-Tocoferol em camundongos \\ Apo E -/-, modelo de doença cardiovascular
}

\begin{abstract}
Maria do Carmo Gouveia Peluzio', Tatiana Fiche Salles Teixeira ${ }^{\mathrm{II}}$, Vanessa Patrocínio Oliveira ${ }^{\mathrm{III}}$, Céphora Maria Sabarense ${ }^{\mathrm{IV}}$, Cristina Maria Ganz Chaves Dias ${ }^{\mathrm{V}}$, Monise Viana Abranches ${ }^{\mathrm{VI}}$, Izabel Regina dos Santos Costa Maldonado ${ }^{\mathrm{VII}}$

${ }^{1}$ Research performed at the Department of Nutrition and Health, Federal University of Viçosa (UFV), Brazil. Part of the Master thesis of Vanessa Patrocinio de Oliveira.

${ }^{\mathrm{I}} \mathrm{PhD}$, Associate Professor, Department of Nutrition and Health, UFV, Viçosa-MG, Brazil. Mentor of Fellow Master degree Vanessa Patrocínio de Oliveira. Responsible for intellectual, scientific content of the study and critical revision.

${ }^{\text {II }}$ Fellow Master degree, Department of Nutrition and Health, UFV, Viçosa-MG, Brazil. Manuscript writing and responsible for English language.

III Master, Department of Nutrition and Health, UFV, Viçosa-MG, Brazil. Involved with technical procedures and experiment conduction.

${ }^{\mathrm{IV}} \mathrm{PhD}$, Associate Professor, Department of Biochemistry, Federal University of Juiz de Fora, Minas Gerais, Brazil. Designed the protocol and critical revision.

${ }^{\mathrm{v}} \mathrm{PhD}$, Associate Professor, Department of Medicine, UFV, Viçosa-MG, Brazil. Designed the protocol for identification and histological classification of the lesions.

${ }^{\mathrm{V}}$ Fellow PhD degree, Department of General Biology, UFV, Viçosa-MG, Brazil. Helped with technical procedures and analysis of data.

${ }^{\text {VII }} \mathrm{PhD}$, Associate Professor, Department of General Biology, UFV, Viçosa-MG, Brazil. Macroscopic and histopathological examinations.
\end{abstract}

\begin{abstract}
Purpose: To verify the effect of consumption of grape extract isolated or combined with $\alpha$-tocopherol supplementation on atherosclerosis model with Apo E -/- mice. Methods: After six weeks of atherogenic diet, Apo E -/- mice were divided into the following groups: Control, Grape, Tocopherol and Grape plus Tocopherol. The treatment progressed for 11 weeks when animals were submitted to euthanasia. Results: All the treatments presented hypocholesterolemic effect with reduction of serum and liver cholesterol levels. This effect was parallel to an increase in the fecal excretion of cholesterol. There was also a higher fecal excretion of saturated fatty acids in groups receiving grape extract or $\alpha$-tocopherol. All the groups treated presented a tendency to show higher levels of vitamin E. The fatty acid profile showed a tendency for monounsaturated fatty acid preservation after grape extract and $\alpha$-tocopherol consumption. Morphological analysis revealed a lower degree of evolution of the atherosclerotic plaque of the animals that were fed $\alpha$-tocopherol combined with grape extract, even when no difference was found in the size of the largest lesion. Conclusion: A synergistic effect between the polyphenols and $\alpha$-tocopherol was observed, resulting in diminished evolution of atherosclerosis and a greater beneficial effect on atherosclerosis than the isolated consumption of antioxidants.
\end{abstract}

Key words: Cholesterol, LDL. Vitis. alpha-Tocopherol. Diet, Atherogenic. Mice.

\section{RESUMO}

Objetivo: Verificar o efeito do consumo de extrato de uva isolada ou combinada com a suplementação de $\alpha$-tocoferol em modelo de aterosclerose, utilizando camundongos Apo E -/-. Métodos: Os camundongos Apo E -/- foram tratados com dieta aterogênica por seis semanas e foram divididos em quatro grupos: Controle, Uva, Tocoferol e Uva e Tocoferol. Após 11 semanas de tratamento os animais foram submetidos à eutanasia. Resultados: Todos os tratamentos apresentaram efeito hipocolesterolêmico, com redução de colesterol plasmático e hepático. Este efeito foi acompanhado de um aumento na excreção fecal de colesterol. Houve também uma maior excreção fecal de ácidos graxos saturados nos grupos que receberam extrato de uva ou de $\alpha$-tocoferol. Todos os grupos apresentaram uma tendência a apresentar níveis mais elevados de vitamina E. O perfil de ácidos graxos mostrou uma tendência para a preservação de ácidos graxos monoinsaturados, após consumo de extrato de uva e $\alpha$-tocoferol. A análise morfológica revelou um menor grau de evolução da placa aterosclerótica dos animais que foram alimentados com $\alpha$-tocoferol combinado com extrato de uva, mesmo quando não houve diferença no tamanho da lesão. Conclusão: Foi observado um efeito sinergístico entre os polifenóis e $\alpha$-tocoferol, resultando na redução na evolução da aterosclerose e um maior de efeito benéfico na aterosclerose do que o consumo isolado de antioxidantes sobre a aterosclerose do que o consumo isolado de antioxidantes.

Descritores: Colesterol LDL. Vitis. alfa-Tocoferol. Dieta Aterogênica. Camundongos. 


\section{Introduction}

The main causes of death in the western societies are cardiovascular diseases, whose major manifestations are: heart attacks, embolisms, and cerebral vascular accidents $(\mathrm{CVA})^{1}$. Atherosclerosis is the main alteration involved in the process of cardiovascular diseases. It is characterized by the formation of atheroma plaques from the accumulation of lipids inside the macrophages, which is subsequently deposited in the vascular intima triggering an inflammatory response. This process seems to be directly linked with oxidative modification of the low-density lipoprotein-LDL (Low Density Lipoprotein) in the circulation².

Therefore, oxidative modifications within the arterial wall may initiate and/or contribute to atherogenesis. The shift in the balance between oxidants and antioxidants in favor of the former would be one of the factors contributing to inflammatory responses and to a vicious cycle of lipid peroxidation within the lipoproteins and cellular recruitment for uptake of modified lipoproteins from circulation $^{3}$.

Many factors could contribute to compromise endogenous antioxidant defense system like high exposure to pathological agents of different origins or even a deficient diet ${ }^{4}$. In the context of the oxidative modification hypothesis, antioxidant protection of LDL in the extracellular space deserves focus, as oxidized LDL has many potential proatherogenic activities. Thus, the use of antioxidants through the diet could be a useful therapeutic measure applicable against LDL oxidative modification.

Compounds able to prevent the consequences of radicals involved in lipid peroxidation through its inactivation could contribute to the maintenance of health or to reduce progression of atherosclerotic lesions. Red wine, white wine and grape juice all have high antioxidant potential to protect cellular structures against peroxidation reactions owing to their rich phenolic contents ${ }^{5}$. Grape juice is a rich source of antioxidant compounds as the flavonoids catechin, epicatechin, quercetin, and anthocyanins ${ }^{6}$. In vitro studies showed that grape juice has sufficient antioxidant activity to inhibit LDL oxidation ${ }^{7}$. At the same time high-dose $\alpha$-tocopherol supplementation in humans decreases the susceptibility of LDL oxidation. Jialal et $a l .^{8}$ compared the effect of $\alpha$-tocopherol in doses of $60,200,400,800$, and $1200 \mathrm{IU} / \mathrm{d}$, and found that the minimum dose of $\alpha$-tocopherol needed to significantly decrease the susceptibility of LDL to oxidation is $400 \mathrm{IU} / \mathrm{d}$.

To better understand the action of dietary antioxidants on atherogenesis, this work was carried out to evaluate the influence of diet supplementation with grape juice extracted from Niagara grape (Vitis vinifera L.) and $\alpha$-tocopherol on the development of atherosclerosis in Apo E-/- mice and the likely synergistic effect of the simultaneous use of antioxidants.

\section{Methods}

Animals and diets

A total of 49 Apo E gene deficient 57BL/6 male and female mice of same age and similar weights were selected. The 5 -week old animals were fed atherogenic diet for six weeks. After this period, the animals were separated into 4 groups with different treatments. The experimental treatments consisted in: a) Control, fed atherogenic diet and water; b) Grape, fed atherogenic diet and Niagara grape extract; c) Tocopherol, fed atherogenic diet supplemented with $400 \mathrm{mg}$ of $\alpha$-tocopherol acetate $/ \mathrm{Kg}$ of diet and water; and d) Grape /Tocopherol, fed atherogenic diet supplemented with $400 \mathrm{mg}$ of $\alpha$-tocopherol acetate $/ \mathrm{Kg}$ of diet and Niagara grape extract diet. The diet, grape extract and water were given ad libitum and food intake was followed up weekly. The treatment lasted 11 weeks when the animals were euthanized.

The experimental diets were prepared according to A.O.A.C. protocol $1989^{9}$. The aqueous grape extract was prepared using $1.5 \mathrm{~kg}$ of Niagara grape (Vitis vinifera L.) produced in northwestern São Paulo, Brazil, and purchased at a market in ViçosaMG, Brazil. The grapes were processed with seeds in a domestic blender with a total of $20 \mathrm{~mL}$ of distilled water and filtrated in a cotton cloth. The extract was stored at $-25^{\circ} \mathrm{C}$, protected from light and oxygen. The dilution of the concentrated extract was made in the proportion 1:5 (extract/distilled water) for animal consumption.

Experimental protocols used on this research were developed following Animal Experimentation Brazilian College rules and management recommendations.

\section{Cholesterol and triacylglycerol dosage}

Total cholesterol and triacylglycerol dosage in the serum, liver, and feces was performed by means of enzymatic kits (donated by KATAL and Bioclin Laboratories). Cholesterol and triacylglycerol were extracted from liver and feces according to Folch et al. ${ }^{10}$

\section{Vitamin E dosage}

Serum and liver vitamin E levels were analyzed by High-Performance Liquid Chromatography (HPLC), after vitamin extraction according to the method proposed by Ueda and Igarashi ${ }^{11}$. 
The equipment consisted of a visible UV diode array detector (Shimadzu), Lichrospher column, RP-18 (4.0 x 250 mm, $5 \mu \mathrm{m})$. A mixture of acetonitrila, methanol and hexane was used as mobile phase in the ratio 3:95:2. Running flow was $1 \mathrm{~mL} /$ minute and running time was 10 minutes. The wavelength used in the detector corresponded to a maximum absorbance of $\alpha$-tocopherol, $295 \mathrm{~nm}$. The vitamin standard applied was $\alpha$-tocopherol (Sigma-Aldrich ${ }^{\circledR}$, EUA), dissolved in ethanol at $96 \%$, resulting in a stock solution of $100 \mu \mathrm{g} / \mathrm{mL}$.

\section{Soluble polyphenol dosage}

Polyphenol determination was carried out in the grape extract, serum, liver and feces according to the method of Singleton and Rossi ${ }^{12}$, using gallic acid as standard.

\section{Determination of the anthocyanins in the grape extract}

Anthocyanin content was obtained based on the technique proposed by Lees and Francis ${ }^{13}$.

\section{Malondialdehyde (MDA) dosage}

Malondialdehyde (MDA) levels were determined in the liver according to the method developed by Gutteridge and Halliwell ${ }^{14}$.

\section{Lipid hydroperoxide dosage}

Lipid peroxidation sub-products capable of oxidizing ferrous ions $\left(\mathrm{Fe}^{3+}\right)$ into ferric $\left(\mathrm{Fe}^{2+}\right)$ were determined in the serum and liver, according to the method proposed by Nourooz-Zadeh et al. ${ }^{15}$

\section{Fatty acid profile analysis}

After lipid extraction from the liver and fecal tissues, saponification and esterification of the lipid extracts was carried out for gas chromatography (GC) analysis. The methodology applied for saponification and esterification of the lipid extract was proposed by Hartman and Lago ${ }^{16}$. For the chromatographic running, an aliquot of $1 \mu \mathrm{L}$ of the lipid extract solution was injected in hexane $(50 \mathrm{mg} /$ $\mathrm{mL}$ ) in CG-17 ${ }^{\mathrm{A}}$ Shimadzu/Class chromatograph, equipped with SP2560 (biscianopro2pil polysiloxane) used silica chromatographic column of $100 \mathrm{~m}$ and $0.25 \mathrm{~mm}$ diameter. The carrier gas (mobile phase) was nitrogen. Running started with the column temperature at $100^{\circ} \mathrm{C}$, increasing $10^{\circ} \mathrm{C} / \mathrm{min}$ until reaching $180^{\circ} \mathrm{C}$. After this period, the column temperature increased $1^{\circ} \mathrm{C} / \mathrm{min}$ until reaching $240^{\circ} \mathrm{C}$, remaining at this temperature for $10 \mathrm{~min}$. The injector and detector temperatures were $250^{\circ} \mathrm{C}$ and $270^{\circ} \mathrm{C}$, respectively. Fatty acid identification considered the retention times of a standard fatty acid methyl ester (Supelco ${ }^{\mathrm{TM}} 37$ Component FAME Mix).

\section{Morphological and morphometrical analyses}

Morphological analysis of aorta artery was carried out according to classification proposed by Stary et al. ${ }^{17}$ The presence of specific histopathologic characteristics of six different degrees of atherosclerotic lesion was considered.

The morphometrical analysis was carried out using the area average of the three major lesions of each animal. The optical microscope Olympus Provis U-MCB, coupled to a Spot Insight Color digital camera and computer, was used to capture the images. The images were measured by means of the software Image-Pro Plus 4.5.

\section{Ethics committee}

This project was approved by the Ethics Committee of the Department of Veterinary Medicine of the Federal University of Viçosa, processed 13/2008, and the experiment was carried out according to the Ethical Principles in Animal Experimentation, adopted by the Brazilian College of Animal Experimentation (COBEA).

\section{Statistical analysis}

The ANOVA analysis of variance and Tukey test was used for comparison of symmetric data. The non-parametric test of Kruskal - Wallis complemented by the Dunn's test of multiple comparisons was used for asymmetric data. For histological analysis, the statistical Qui-square test was applied. A significant level (p) below 5\% was accepted, conferring the study a reliability of $95 \%$. For data analysis, the software Sigma Stat 2.03 and the software EpiInfo 6 was used.

\section{Results}

Animals and diets

The results did not show treatment influences on weighted gain, liver relative weight, and food consumption. The levels of 
total polyphenols in the pure extract was $331.00 \pm 51.00 \mathrm{mg} / 100 \mathrm{~g}$ and anthocyanins $248.75 \pm 132.45 \mathrm{mg} / 100 \mathrm{~g}$. Animals consumed an average of $9.7 \mathrm{~mL}$ daily, with a consumption of $32.11 \mathrm{mg}$ of polyphenols and $24.13 \mathrm{mg}$ of anthocyanins. Alpha-tocopherol consumption was estimated to be ten times higher in those groups receiving this vitamin: $0.018,0.175,0.019$ and $0.179 \mathrm{mg} /$ week/ animal in the control, tocopherol, grape, and tocopherol plus grape, respectively.

\section{Cholesterol and triacylglycerol levels}

The antioxidants supplementation was effective in influencing total serum cholesterol levels, specially the association of both antioxidants. Treated groups presented 15.71\%, 35.8\% and $43.5 \%$ smaller cholesterol levels in comparison with control group in animals given grape extract, $\alpha$-tocopherol and both the antioxidants respectively. The smallest content of cholesterol in the liver was found in the group consuming grape extract in association with $\alpha$-tocopherol, followed by animals fed only $\alpha$-tocopherol and grape extract. The vitamin supplementation resulted in the highest level of cholesterol in feces samples, and the consumption of grape extract alone also favored presence of higher levels of cholesterol in feces in comparison with control animals (Table 1), suggesting that these treatments might have been effective in exerting hipocholesterolemic effect through fecal excretion mechanism.

The treatments did not influence the serum and liver triacylglycerol levels. However, grape extract intake led to a significant increase in total triacylglycerol fecal excretion compared with control (Table 1).

TABLE 1 - Apo E-/- mice experimental groups' serum, liver and fecal total cholesterol and triacylglycerol levels.

\begin{tabular}{|c|c|c|c|c|}
\hline Lipid & Control & Tocopherol & Grape & $\begin{array}{l}\text { Grape and } \\
\text { Tocopherol }\end{array}$ \\
\hline Total Cholesterol & $n=12$ & $n=9$ & $n=12$ & $n=12$ \\
\hline $\operatorname{Serum}(\mathrm{mg} / \mathrm{dL})$ & $1024.71 \pm 83,21$ & $657.36 \pm 69.65^{*}$ & $863.74 \pm 132.47^{*}$ & $578.56 \pm 196.27^{*}$ \\
\hline Liver $(\mathrm{mg} / \mathrm{g})$ & $25.78 \pm 2.61$ & $13.20 \pm 3.13^{*}$ & $14.23 \pm 3.32^{*}$ & $8.39 \pm 2.01^{* \dagger}$ \\
\hline $\operatorname{Fecal}(\mathrm{mg} / \mathrm{g})^{*}$ & $14.77 \pm 2.52$ & $24.97 \pm 0.54^{* \dagger}$ & $22.21 \pm 3.63^{* \neq}$ & $18.27 \pm 1.91^{* * \neq}$ \\
\hline Triacilglycerol & $n=6$ & $n=6$ & $n=6$ & $n=6$ \\
\hline $\operatorname{Serum}(\mathrm{mg} / \mathrm{dL})$ & $204.07 \pm 90.00$ & $132.21 \pm 30.01$ & $146.07 \pm 62.77$ & $127.43 \pm 45.17$ \\
\hline Liver $(\mathrm{mg} / \mathrm{g})$ & $85.78 \pm 24.58$ & $87.41 \pm 12.94$ & $63.34 \pm 14.67$ & $83.68 \pm 24.12$ \\
\hline $\mathrm{Fecal}(\mathrm{mg} / \mathrm{g})$ & $2.04 \pm 1.07$ & - & $17.21 \pm 3.54^{*}$ & $17.91 \pm 1.20^{*}$ \\
\hline
\end{tabular}

Data are given as means \pm SEM $* \mathrm{p}<0.05$ compared with control group. $\dagger \mathrm{p}<0.05$ compared with grape group. $\$ \mathrm{p}<0.05$ compared with tocopherol goup (ANOVA analysis of variance).

\section{Serum and liver vitamin E levels and soluble polyphenol}

The use of antioxidants as part of the diet tended to enhance vitamin E serum levels around 2.2,2.8 and 3.7 times respectively in animals receiving tocopherol, grape extract and tocopherol + grape compared to control group, although no statistical significance was found. While groups receiving grape extract, either isolated or in association with -tocopherol, presented higher vitamin E serum levels, their hepatic content of this vitamin was smaller in relation to control group (Table 2).

The grape extract treatment did not alter the serum and liver levels of polyphenols; however, the groups receiving grape extract presented fecal content of polyphenols smaller than control and tocopherol group (Table 2).

TABLE 2 - Apo E-/- mice experimental groups' serum, liver and fecal vitamin $\mathrm{E}$ and soluble polyphenol levels.

\begin{tabular}{|c|c|c|c|c|}
\hline Parametrer & Control & Tocopherol & Grape & $\begin{array}{l}\text { Grape and } \\
\text { Tocopherol }\end{array}$ \\
\hline Vitamin $E$ & $n=6$ & $n=5$ & $n=5$ & $N=7$ \\
\hline $\begin{array}{l}\text { Serum }(\mathrm{mg} / \mathrm{dL}) \\
\text { Stample pool }\end{array}$ & 2.24 & 4.95 & 6.45 & 8.25 \\
\hline Liver $(\mu \mathrm{g} / \mathrm{g})$ & $16.23 \pm 1.96$ & $19.79 \pm 6.89$ & $6.93 \pm 1.70^{*}$ & $8.90 \pm 2.27^{* *}$ \\
\hline Soluble polyphenal & $n=10$ & $n=9$ & $n=10$ & $n=10$ \\
\hline $\operatorname{Serum}(\mathrm{mg} / \mathrm{dL})$ & $4.33 \pm 0.81$ & $4.81 \pm 0.27$ & $4.15 \pm 0.60$ & $4.28 \pm 1.47$ \\
\hline Liver (mg/g) & $6.82 \pm 2.66$ & $7.44 \pm 3.44$ & $4.29 \pm 2.01$ & $4.69 \pm 1.84$ \\
\hline Fecal(mg/g) & $1.68 \pm 0.27$ & $1.94 \pm 0.07$ & $0.58 \pm 0.13^{*}$ & $0.70 \pm 0.17^{* \neq}$ \\
\hline
\end{tabular}

Data are given as means \pm SEM. $* \mathrm{p}<0.05$ compared with control group. $\dagger \mathrm{p}<0.05$ compared with grape group. $\$ \mathrm{p}<0.05$ compared with tocopherol goup (ANOVA analysis of variance).

\section{Malondialdehyde and lipid hydroperoxide}

The treatments did not influence the liver levels of MDA and the lipid hydroperoxide levels. However, these levels tended to reduce with consumption of both antioxidants (Data not shown).

\section{Liver and fecal fatty acid profile}

Interventions with antioxidants had different impact on the fatty acid profile of the liver: supplementation with $\alpha$-tocopherol preserved oleic fatty acid (C18:1) as compared with grape extract consumption, while the group fed grape extract presented a higher DHA (C22:6) fatty acid percentage (Table 3 ). 
TABLE 3 - Apo E-/- mice experimental groups' liver fatty acid profile.

\begin{tabular}{|c|c|c|c|c|}
\hline $\begin{array}{c}\text { Fatty acids } \\
(\%)\end{array}$ & $\begin{array}{c}\text { Control } \\
(n=12)\end{array}$ & $\begin{array}{c}\text { Tocopherol } \\
(\mathrm{n}=9)\end{array}$ & $\begin{array}{l}\text { Grape } \\
(n=14)\end{array}$ & $\begin{array}{c}\text { Grape and } \\
\text { Tocopherol } \\
(n=13)\end{array}$ \\
\hline Saturated & $39.06 \pm 21.15$ & $32.62 \pm 6.19$ & $24.10 \pm 18.72$ & $27.77 \pm 17.96$ \\
\hline $\mathrm{C} 16: 0$ & $36.19 \pm 7.72$ & $29.50 \pm 5.69$ & $31.87 \pm 9.08$ & $31.98 \pm 11.09$ \\
\hline $\mathrm{C} 18.0$ & $4.94 \pm 2.30$ & $4.37 \pm 1.63$ & $6.98 \pm 3.62$ & $7.45 \pm 4.72$ \\
\hline Monounsaturated & $48.06 \pm 5.03$ & $49.13 \pm 13.08$ & $36.39 \pm 13.66$ & $39.75 \pm 9.54$ \\
\hline $\mathrm{C} 16: 1$ & $48.06 \pm 5.03$ & $2.93 \pm 1.08$ & $2.46 \pm 1.63$ & $2.44 \pm 0.99$ \\
\hline $\mathrm{C} 18: 1$ & $2.51 \pm 0.83$ & $47.50 \pm 14.13^{\dagger}$ & $32.57 \pm 14.30^{*}$ & $36.97 \pm 8.25$ \\
\hline Polyunsaturated & $43.58 \pm 7.77$ & $24.53 \pm 11.91$ & $34.35 \pm 14.64$ & $31.08 \pm 8.51$ \\
\hline $\mathrm{C} 18: 2 \omega 6$ & $26.49 \pm 7.02$ & $20.02 \pm 10.06$ & $12.53 \pm 2.12$ & $13.19 \pm 2.36$ \\
\hline $\mathrm{C} 18: 3 \omega 3$ & $14.57 \pm 2.72$ & ND & $0.84 \pm 0.37$ & ND \\
\hline $\mathrm{C} 20: 4 \omega 6$ & $1.35 \pm 0.08$ & $5.78 \pm 1.38$ & $11.88 \pm 6.16$ & $10.04 \pm 4.38$ \\
\hline $\mathrm{C} 22: 6 \omega 3$ & $8.20 \pm 2.50$ & $4.70 \pm 1.94$ & $10.64 \pm 6.17$ & $7.48 \pm 1.97$ \\
\hline
\end{tabular}

Data are given as means \pm SEM. ${ }^{*} \mathrm{p}<0.05$ compared with control group. $\dagger \mathrm{p}<0.05$ compared with grape group. $\$ \mathrm{p}<0.05$ compared with tocopherol goup (ANOVA analysis of variance). $\mathrm{ND}=$ undetermined value.

Fecal fatty acid profile was reduced in DHA when the animals were fed $\alpha$-tocopherol, suggesting that this vitamin may contribute to DHA absorption. The antioxidant treatments provided a slight increase in the fecal excretion of saturated fatty acids and smaller excretion of mono and polyunsaturated fatty acids (Table 4).

TABLE 4 - Apo E-/- mice experimental groups' fecal fatty acid profile.

\begin{tabular}{|c|c|c|c|c|}
\hline $\begin{array}{c}\text { Fatty acids } \\
(\%)\end{array}$ & $\begin{array}{c}\text { Control } \\
(n=6)\end{array}$ & $\begin{array}{c}\text { Tocopherol } \\
(\mathbf{n}=6)\end{array}$ & $\begin{array}{c}\text { Grape } \\
(n=6)\end{array}$ & $\begin{array}{c}\text { Grape and } \\
\text { Tocopherol } \\
(\mathrm{n}=6)\end{array}$ \\
\hline Saturaded & $24.61 \pm 18.41$ & $74.41 \pm 6.35$ & $37.23 \pm 18.53$ & $41.03 \pm 37.59$ \\
\hline C16:0 & $17.63 \pm 11.13$ & $22.92 \pm 1.88$ & $24.89 \pm 0.87$ & $22.48 \pm 3.43$ \\
\hline C18:0 & $22.03 \pm 0.17$ & $46.48 \pm 5.06^{*}$ & $37.13 \pm 1.95^{*}$ & $30.27 \pm 2.08$ \\
\hline Monounsaturated & $32.00 \pm 31.64$ & $20.36 \pm 4.70$ & $22.36 \pm 24.36$ & $20.43 \pm 17.70$ \\
\hline C18:1 & $23.30 \pm 19.68$ & $17.84 \pm 19.68$ & $15.53 \pm 5.84$ & $21.91 \pm 7.17$ \\
\hline Polyunsaturated & $29.47 \pm 14.42$ & $23.23 \pm 32.18$ & $19.80 \pm 2.27$ & $14.37 \pm 5.06$ \\
\hline $\mathrm{C} 18: 2 \omega 6$ & $8.04 \pm 2.51$ & $4.08 \pm 0.71$ & $5.22 \pm 1.64$ & $5.22 \pm 2.92$ \\
\hline $\mathrm{C} 22: 6 \omega 3$ & $19.71 \pm 4.69$ & $3.71 \pm 3.80^{*}$ & $14.58 \pm 3.89$ & $9.75 \pm 6.48$ \\
\hline
\end{tabular}

Data are given as means \pm SEM. ${ }^{*} \mathrm{p}<0.05$ compared with control group. $\dagger \mathrm{p}<0.05$ compared with grape group. $\$ \mathrm{p}<0.05$ compared with tocopherol goup (ANOVA analysis of variance).

\section{Morphological analysis of aorta}

In the morphological analysis of the sections, no difference was observed in relation to size of the atherosclerotic lesion area, but about the degree of atherosclerotic lesion development. The group receiving the grape extract combined with $\alpha$-tocopherol didn't present any lesion at advanced stage. Animals receiving just $\alpha$-tocopherol supplementation showed a better profile of lesion classification in comparison to control and grape extract group (Table 5).

TABLE 5 - Morphological classification of specific histopathological characteristics of six different degrees of atherosclerotic lesion.

\begin{tabular}{|c|c|c|c|}
\hline \multirow{2}{*}{ Group } & \multicolumn{3}{|c|}{$\begin{array}{c}\text { Proportion of lesion classified at } \\
\text { each stage* development }\end{array}$} \\
\hline & Initial & Intermediate & Advanced \\
\hline Control $(n=12)$ & $0 \%$ & $50 \%$ & $50 \%$ \\
\hline Tocopherol $(\mathrm{n}=8)$ & $37,5 \%$ & $50 \%$ & $12,5 \%$ \\
\hline Grape extrac $(n=15)$ & $13,3 \%$ & $53,3 \%$ & $33,4 \%$ \\
\hline $\begin{array}{l}\text { Grape extract and } \\
\text { tocopherol }(\mathrm{n}=15)^{\dagger}\end{array}$ & $30 \%$ & $70 \%$ & $0 \%$ \\
\hline
\end{tabular}

*According to classification proposed by Stary et al. ${ }^{17}{ }^{\dagger}<0.05$ compared with control group according to chi-square test.

\section{Discussion}

Evidences of polyphenols benefits are usually derived from in vitro or animals experiments which usually applies higher doses than those usually consumed by humans ${ }^{18}$. Our treated mice consumed a dose of approximately $1600 \mathrm{mg}$ of polyphenols $/ \mathrm{kg}$ of body weight and $1200 \mathrm{mg}$ of anthocyanins $/ \mathrm{kg}$ of body weight, a very high quantity if we consider men's average intake of flavonoids assessed by Hertog et al. ${ }^{19}$ around $25 \mathrm{mg}$ /day, which would represents an average dose of $0.33 \mathrm{mg} / \mathrm{kg}$ body weight for an average man of $75 \mathrm{~kg}$. At this relative low level of intake, they found that flavonoid intake was significantly inversely associated with mortality from coronary heart disease in humans.

Administration of grape extract and $\alpha$-tocopherol reduced serum and hepatic cholesterol levels, although this effect has been potentiated when these antioxidants were given together. This hypocholesterolemic effect of the polyphenols was also observed by Yang and $\mathrm{Koo}^{20}$. In their study they used polyphenols from green tea and observed a reduction in the levels of serum and liver cholesterol in hypercholesterolemic mice. The same effect was not observed after vitamin $\mathrm{E}$ intake in a study developed by Peluzio et al. ${ }^{21}$, 
Cyrus et al. ${ }^{22}$ and Koga et al. ${ }^{23}$. These authors did not observed any reduction in the levels of cholesterol in Apo E-/- rats, LDL -/- rats and rabbits, respectively, treated with different doses of vitamin $\mathrm{E}$.

The hypocholesterolemic effect of these antioxidants may be attributed to the action of these substances on cellular metabolism. Polyphenols found in non-alcoholic wine decrease Apo B lipoprotein synthesis by liver cells, thus decreasing the production of lipid-transporting lipoproteins in the plasma. Both, polyphenols ${ }^{24}$ and vitamin $\mathrm{E}^{25}$ seem to increase the expression of LDL receptors in the cells, increasing cholesterol uptake by the liver cells and reducing the cholesterol plasma levels.

The serum and liver levels of the triacylglycerols, on the other hand, were not influenced by the treatments, a result similar to those found by Yang and $\mathrm{Koo}^{20}$, in hypercholesterolemic rats fed green tea polyphenols. In the present study, a significant increase was observed in the fecal excretion of triacylglycerol and cholesterol. This effect could have been attributed to the interaction between polyphenols and the digestive proteins, altering lipid metabolism and reducing the bioavailability of these substances ${ }^{26}$. Polyphenolic substances can have an anti nutritional action compromising intestinal permeability and, consequently, animal nutrition ${ }^{27}$, as well as their interaction with the pancreatic lipases, decreasing the action of the enzyme and compromising the bioavailability of the lipids ${ }^{28}$.

Antioxidant capacity would be related to the modulation of oxidative stress. The progression of the atherosclerotic lesion involves an inflammatory process, where chemokines controls the recruitment of leukocytes within the vascular wall and these activated cells contribute to oxidative stress ${ }^{29}$. Increased serum levels of vitamin $\mathrm{E}$ of the groups treated reflects the enhancement of antioxidant capacity. The groups fed grape polyphenols were found to obtain a similar result regarding vitamin E serum levels to that obtained with $\alpha$-tocopherol supplementation or even superior when the two antioxidants were administered. Such result may have been due to the action of $\alpha$-tocopherol recovery by the polyphenols ${ }^{30}$. However, the results found regarding vitamin E levels in the liver suggest that the presence of polyphenols in the diet could mobilize liver vitamin reserves.

Polyphenols bioavailability determines their effects. Indirect evidence of their absorption through the gut barrier is the increase in the antioxidant capacity of the plasma with polyphenolrich foods ${ }^{18}$. Bub et al. ${ }^{31}$ administered fruit juices providing polyphenolic compounds to men during 2 weeks. Twelve hours after the last ingestion of juices no polyphenols or polyphenol metabolites from either juices were detected in plasma or urine samples, but positive results were found in the group supplemented. In our study, although no difference in plasma and liver polyphenol levels were found between the groups, animals receiving grape extract presented fecal content of polyphenols smaller than control and tocopherol group. This could indicate that supplemented animals absorbed polyphenol from the juice or may have been due to the interaction of the polyphenols with the enteric enzymes. The plasma levels tend to be constant, even during supplementation, when the polyphenol urinary excretion levels seem to increase proportionally to intake increase $\mathrm{e}^{20}$.

Although not presenting any statistical difference, the indicators of peroxidation in the present study tended to reduce these indices in the treatment using both antioxidants. These results were similar to those found by Stoker and O'Halloran ${ }^{32}$, where no differences were observed in lipid peroxidation of ApoE-/-mice treated for 24 weeks with non-alcoholic red wine. Slight increase was observed in the formation of hydrogen peroxides, as in the present study, but with no statistical significance. Kaplan et al. ${ }^{33}$ observed a reduction of $8 \%$ in lipid peroxidation in the plasma of Apo E-/- mice fed pomegranate juice, rich in polyphenols. Blackhurst and Marais ${ }^{34}$ in a study with eutrophic humans did not observe any alteration in lipid peroxidation after red wine intake, although there was a significant increase in the polyphenol plasma levels. Zhao et al. ${ }^{35}$ observed a reduction in lipid peroxidation in Apo E-/- mice fed diet supplemented with vitamin E

Fatty acid change can alter the properties of the cellular membranes and, consequently, their participation in the lipid metabolism ${ }^{36}$. The liver fatty acid profiles were not influenced by the treatments; however, despite non-significant, a greater preservation of the polyunsaturated fatty acids was observed in the polyphenolfed groups (greater preservation of oleic acid in groups treated in comparison to control group). Such result may be an expression of solubility of the antioxidants studied. Hydrophilic phenolic extracts, sequesters of free radicals such as polyphenols, would be more effective antioxidants than the hydrophobic ones, such as vitamin $\mathrm{E}$, in systems where there is an oil-water interface, such as the one found in the liver tissue ${ }^{37}$.

Treatment using antioxidants was not capable of altering lesion size; however, there was a change in the degree of evolution of the atherosclerotic lesion, a result similar to that found by Nakata and $\mathrm{Maeda}^{38}$, where researchers studied food supplementation with vitamin $\mathrm{C}$ in Apo E-/ mice. In the same animal model, Peluzio et $a l .{ }^{21}$ observed a significant reduction in the size of the lesions and smaller development degree, after vitamin E supplementation of 400 $\mathrm{UI} / \mathrm{Kg}$ of diet. Zhao et al. ${ }^{35}$ observed a reduction in atherosclerosis progression following food supplementation of vitamin $\mathrm{E}$, with $2000 \mathrm{UI} / \mathrm{Kg}$ of diet.

The polyphenol study reveals a reduction in the progression 
of the atherosclerotic plaques. Fuhman et al. ${ }^{39}$ observed a reduction in the degree of development of the atherosclerotic lesion after consumption of ginger polyphenols without pre induction of atheromatous plaque. Aviran et al. ${ }^{40}$ and Kaplan et al. ${ }^{41}$ observed reduction in the size of atherosclerotic lesion after pomegranate juice intake. Oral supplementation with non-alcoholic wine ${ }^{32}$ and caffeic acid ${ }^{41}$ were also capable of reducing the development of the atherosclerotic lesion.

\section{Conclusions}

1. Intake of antioxidants, such as the polyphenols found in grape, and $\alpha$-tocopherol had a beneficial effect on atherosclerosis, contributing to reduce the degree of evolution of the atherosclerotic lesion, reduction of serum and liver cholesterol levels, increase of cholesterol and triacylglycerol fecal excretion.

2. A synergistic effect between the polyphenols and $\alpha$-tocopherol was observed, resulting in a greater beneficial effect on atherosclerosis than the isolated consumption of antioxidants.

\section{References}

1. Michell R. Hemodinamic disorders, thromboembolic disease and shock. In: Kumar V, Abbas A, Fausto N, editors. Pathology basic of disease. Philadelphia: Elservier Sauders Company; 2005. p. 119-44.

2. Lusis A. Atherosclerosis. Nature. 2000;407:233-41.

3. Stocker R, Keaney JF, Jr. Role of oxidative modifications in atherosclerosis. Physiol Rev. 2004;84(4):1381-478.

4. Kaliora AC, Dedoussis GVZ, Schmidt H. Dietary antioxidants in preventing atherogenesis. Atherosclerosis. 2006;187(1):1-17.

5. Durak I, Avci A, Kaçmaz M, Büyükkoçak S, Cimen MY, Elgün S, Oztürk HS. Comparison of antioxidant potentials of red wine, white wine, grape juice and alcohol. Curr Med Res Opin. 1999;15(4):31620.

6. Iacopini P, Baldi M, Storchi P, Sebastiani L. Catechin, epicatechin, quercetin, rutin and resveratrol in red grape: Content, in vitro antioxidant activity and interactions. J Food Compos Anal. 2008;21(8):589-98.

7. O'Byrne DJ, Devaraj S, Grundy SM, Jialal I. Comparison of the antioxidant effects of Concord grape juice flavonoids $\alpha$-tocopherol on markers of oxidative stress in healthy adults. Am J Clin Nutr. 2002;76(6):1367-74.

8. Jialal I, Fuller CJ, Huet BA. The effect of \{alpha\}-Tocopherol supplementation on LDL oxidation : a dose-response study. Arterioscler Thromb Vasc Biol. 1995;15(2):190-8.

9. A.O.A.C. Association of Official Analytical Chemistry. Official Methods of Analysis of A.O.A.C. 14 ed. Whashington: A.O.A.C; 1989.

10. Folch J, Lees M, Slaon-Stanley GN. A simple method for the isolation and purification of total lipids from animal tissues. J Biol Chem. 1957;226:497-509.

11. Ueda $\mathrm{T}$, Igarashi O. Determination of vitamin $\mathrm{E}$ in biological specimens and foods by HPLC- Pretreatment of samples and extraction of tocopherols. J Micronutr Anal. 1990;7:79-96.

12. Singleton V, Rossi J. Colorimetry of total phenolics with phosphomolybic-phosphotungstic acid reagents. Am J Enol Vitic.
1965; 146:144-56

13. Lees D, Francis F. Standardization of pigment analyses in cranberries. HortScience. 1972;7:83-4.

14. Gutteridge J, Halliwell B. The mensurement and mechanism od lipid peroxidation in fisiológical systems. Trends Biochem Scl. 1990;15:129-35.

15. Nouzooz-Zadeh J, Tajaddini-Sarmadi J, Wolff SP. Measurement of plasma hydroperoxide concentrations by the ferrous oxidationxylenol orange assay in conjunction with thiphenylphosphine. Anal Biochem. 1994;220:403-9.

16. Hartman L, Lago R. Rapid preparation of fatty acid methyl esters from lipids. Lab Pract. 1973;22:475-7.

17. Stary HC, Chandler AB, Dinsmore RE, Fuster V, Glagov S, Insull W Jr, Rosenfeld ME, Schwartz CJ, Wagner WD, Wissler RW. A definition of advanced types of atherosclerotic lesions and a histological classification of atherosclerosis. A report from the Committee on Vascular Lesions of the Council on Arteriosclerosis, American Heart Association. Circulation. 1995;92(5):1355-74.

18. Scalbert A, Johnson IT, Saltmarsh M. Polyphenols: antioxidants and beyond. Am J Clin Nutr. 2005;81(1):215S-7S.

19. Hertog MGL, Feskens EJM, Kromhout D, Hollman PCH, Katan MB. Dietary antioxidant flavonoids and risk of coronary heart disease: the Zutphen Elderly Study. Lancet. 1993;342(8878):1007-11.

20. Yang TTC, Koo MWL. Inhibitory effect of Chinese green tea on endothelial cell-induced LDL oxidation. Atherosclerosis. 2000;148(1):67-73.

21. Peluzio MCG, Homem APP, Cesar GC, Azevedo GS, Amorim R, Cara DC, Saliba H, Vieira EC, Arantes RE, Alvarez-Leite J. Influences of alpha-tocopherol on cholesterol metabolism and fatty streak development in apolipoprotein E-deficient mice fed an atherogenic diet. Braz J Med Biol Res. 2001;34:1539-45.

22. Cyrus T, Yao Y, Rokach J, Tang LX, Pratico D. Vitamin E reduces progression of atherosclerosis in low-density lipoprotein receptordeficient mice with established vascular lesions. Circulation. 2003;107(4):521-3.

23. Koga T, Kwan P, Zubick L, Ameho C, Smith D, Meydani M. Vitamin E supplementation suppress macrophage accumulation an endothelial cell expression of adhesion molecules in aorta of hypercolesterolemic rabbits. Atherosclerosis. 2004;176:265-72.

24. Pal S, Thomson AM, Bottema CD, Roach PD. Alpha-tocopherol modulates the low desity receptor for human HepG2 cells. Nutr J. 2003;2(3).

25. Pal S, Ho N, Santos C, Dubois P, Mamo J, Croft K, Allister E. Red wine polyphenolics increase LDL receptor expression and activity and suppress the secretion of ApoB100 from human HepG2 cells. J Nutr. 2003;133(3):700-6.

26. Cook NC, Samman S. Flavonoids - Chemistry, metabolism, cardioprotective effects, and dietary sources. J Nutr Biochem. 1996;7(2):66-76.

27. Jensen-Jarolim E, Gajdzik L, Haberl I, Kraft D, Scheiner O, Graf J. Hot spices influence permeability of human intestinal epithelial monolayers. J Nutr. 1998;128(3):577-81.

28. Sosoulski F. Organoleptic and nutricional effect os fenolic compounds on oliseed protein products: a review. J Am Oil Chem Soc. 1979;56(711).

29. Barlic J, Murphy PM. Chemokine regulation of atherosclerosis. J Leukocyte Biol. 2007;82(2):226-36.

30. Zhu QY, Huang Y, Chen Z-Y. Interaction between flavonoids and $\alpha$-tocopherol in human low density lipoprotein. J Nutr Biochem. 2000;11(1):14-21.

31. Bub A, Watzl B, Blockhaus M, Briviba K, Liegibel U, Müller H, Pool-Zobel BL, Rechkemmer G. Fruit juice consumption modulates antioxidative status, immune status and DNA damage. J Nutr 
Biochem. 2003;14(2):90-8.

32. Stocker R, O'Halloran RA. Dealcoholized red wine decreases atherosclerosis in apolipoprotein E gene-deficient mice independently of inhibition of lipid peroxidation in the artery wall. Am J Clin Nutr. 2004;79(1):123-30.

33. Kaplan M, Hatek T, Raz A, Coleman R, Dornfeld L, Vaya J, Aviram M. Pomegranate juice supplementation to atherogenic mice reduces macrophage lipid peroxidation, cellular cholesterol accumulation and development of atherosclerosis. J Nutr. 2001;131:2082-9.

34. Blackhurst DM, Marais AD. Concomitant consumption of red wine and polyunsaturated fatty acids in edible oil does not influence the peroxidation status of chylomicron lipids despite increasing plasma catechin concentration. Nutr Metab Cardiovasc Dis. 2006;16(8):5508.

35. Zhao L, Praticò D, Rader D, Funk C. 12/15-Lipoxygenase gene disruption and vitamin $\mathrm{E}$ administration diminish atherosclerosis and oxidative stress in apolipoprotein E deficient mica through a final common pathway. Proatag Oth Lipid M. 2005;78:185-93.

36. Kummerow FA. Modification of cell membrane composition by dietary lipids and its implications for atherosclerosis. Ann NY Acad Sci. 1983;414(1):29-43.

37. Porter W. Paradoxal behavior of antioxidants in food and biological systems. In: Willian G, editor. Antioxidants: chemical, physiological, nutricional and toxicological aspects: Princeton Scientific; 1993. p.93-122.
38. Nakata Y, Maeda N. Vulnerable atherosclerotic plaque morphology in apolipoprotein E-deficient mice unable to make ascorbic acid. Circulation. 2002;105(12):1485-90.

39. Fuhrman B, Rosenblat M, Hayek T, Coleman R, Aviram M. Ginger extract consumption reduces plasma cholesterol, inhibits ldl oxidation and attenuates development of atherosclerosis in atherosclerotic, apolipoprotein E-deficient mice. J Nutr. 2000;130(5):1124-31.

40. Aviram M, Dornfeld L, Rosenblat M, Volkova N, Kaplan M, Coleman R, Hayek T, Presser D, Fuhrman B. Pomegranate juice consumption reduces oxidative stress, atherogenic modifications to LDL, and platelet aggregation: studies in humans and in atherosclerotic apolipoprotein E-deficient mice. Am J Clin Nutr. 2000;71(5):106276.

41. Hishikawa K, Nakaki T, Fujita T. Oral flavonoid supplementation attenuates atherosclerosis development in apolipoprotein E-deficient mice. Arterioscler Thromb Vasc Biol. 2005;25(2):442-6.

\section{Acknowledgements}

We are grateful to FAPEMIG to the financial support and KATAL for providing the enzymatic kits.

\section{Correspondence:}

Maria do Carmo Gouveia Peluzio

Universidade Federal de Viçosa

Depto. Nutrição e Saúde

Av. Peter Henry Rolfs, s/n

36570-000 Viçosa - MG Brasil

Tel: (55 31)3899-1275

Fax: (55 31)3899-2541

mpeluzio@ufv.br
Conflict of interest: none

Financial source: CNPq, FAPEMIG, CAPES

Received: December 15, 2010

Review: February 17, 2011

Accepted: March 18, 2011 